\title{
Kynurenic acid and its analogue can alter the opioid receptor G-protein signaling after acute treatment via NMDA receptor in rat cortex and striatum
}

Reza Samavati ${ }^{1,4}$, Ferenc Zádor ${ }^{1, *}$, Edina Szücs ${ }^{1}$, Bernadett Tuka ${ }^{2,3}$, Diána Martos ${ }^{2}$, Gábor Veres ${ }^{2,3}$, Róbert Gáspár ${ }^{4}$, István Mándity ${ }^{5}$, Ferenc Fülöp ${ }^{5}$, László Vécsei ${ }^{2,3}$, Sándor Benyhe ${ }^{1}$, Anna Borsodi $^{1,6}$

1 Institute of Biochemistry, Biological Research Center, Hungarian Academy of Sciences, Temesvári krt. 62., H-6726, Szeged, Hungary

${ }^{2}$ Department of Neurology, Faculty of Medicine, University of Szeged, Semmelweis utca 6., H6725, Szeged, Hungary

${ }^{3}$ MTA-SZTE Neuroscience Research Group, University of Szeged, Semmelweis utca 6., H-6725, Szeged, Hungary

${ }^{4}$ Institute of Pharmacodynamics and Biopharmacy, Faculty of Pharmacy, University of Szeged, Eötvös u. 6, 6720, Szeged, Hungary

${ }^{5}$ Institute of Pharmaceutical Chemistry, Faculty of Pharmacy, University of Szeged, Eötvös u. 6, 6720, Szeged, Hungary

${ }^{6}$ Bio-Targeting Ltd., Vitez u. 1, 6722, Szeged, Hungary

*Corresponding author:

Ferenc Zádor Institute of Biochemistry, Biological Research Center, Hungarian Academy of Sciences H-6726 Szeged, Temesvári krt. 62., Hungary

Tel: +36-62-599-636

Fax: +36-62-433-506

Email: zador.ferenc@gmail.com 


\begin{abstract}
Previously, we have shown that the N-methyl D-aspartate (NMDA)-receptor antagonist kynurenic acid (KYNA) and its analogue KYNA1 do not bind directly to mu, kappa and delta opioid receptors in vitro. On the other hand, chronic administration of KYNA and KYNA1 resulted in region (cortex vs striatum) and opioid receptor-type specific alterations in G-protein activation of mouse brain homogenates. Here we describe for the first time the acute effect of KYNA and KYNA1 on opioid receptor function with the possible involvement of the NMDA receptor.

The acute 30 minutes in vivo KYNA1 and KYNA treatments altered opioid receptor Gprotein signaling or ligand potency depending on the opioid receptor type and brain region (rat cortex vs. striatum) using $\left[{ }^{35} \mathrm{~S}\right] \mathrm{GTP} \gamma \mathrm{S}$ binding assays. Pretreatment with the NMDA receptor antagonist MK-801 impaired or reversed the effects of KYNA1 and KYNA. These results suggest an NMDA receptor mediated effect. After acute 30 minutes treatment HPLC measurements revealed a similar KYNA1 and a higher KYNA plasma concentration compared to cerebrospinal fluid concentrations. Finally, KYNA, KYNA1 and MK-801 showed comparable results in opioid receptor G-protein activity and ligand potency with acute in vivo treatments when they were administered in vitro for 30 minutes on isolated cortex and striatum slices.

We previously demonstrated that KYNA1 and KYNA acutely altered opioid receptor function in vivo and in vitro through the NMDA receptor depending on the opioid receptor type and brain region. This study may lead to a new, indirect approach to influence opioid receptor signaling.
\end{abstract}

Keywords: KYNA; Opioid receptor; $\left[{ }^{35} \mathrm{~S}\right] \mathrm{GTP} \gamma \mathrm{S}$ binding; G-protein; MK-801 


\section{LIST OF ABBREVIATIONS}

3-NLT: 3-nitro-L-tyrosine

CNS: central nerve system

CSF: cerebrospinal fluid

BBB: blood-brain barrier

DAMGO: Tyr-D-Ala- Gly-(NMe)Phe-Gly-ol

DOPr: $\delta$ opioid peptide receptor

EGTA: ethylene glycol tetraacetic acid

GDP: guanosine 5'-diphosphate

GPCR: G-protein coupled receptor

GTP: guanosine 5'-triphosphate

GTP $\gamma$ S: Guanosine-5'-O-[ $\gamma$-thio] triphosphate

KOPr: $\kappa$ opioid peptide receptor

KYNA: kynurenic acid

MOPr: $\mu$ opioid peptide receptor

S.E.M.: standard error of means

TEM: Tris-HCl, EGTA, $\mathrm{MgCl}_{2}$

Tris-HCl: tris-(hydroxymethyl)-aminomethane hydrochloride 


\section{INTRODUCTION}

The kynurenine pathway of the tryptophan metabolism has emerged in recent years as a key regulator of the production of both neuroprotective (e.g., kynurenic acid), and neurotoxic metabolites such as 3-hydroxykynurenine (Lovelace et al., 2016). Kynurenic acid (KYNA) (Fig.1A) is a glutamate receptor antagonist (Stone \& Darlington, 2013) and acts as an agonist on GPR35 receptors (Resta et al., 2016). It has been proven that KYNA plays an important role in endogenous protective mechanisms, therefore it is a good target for pathophysiologycal investigation of certain neurodegenerative disorders like Huntington's and Parkinson's disease (Zádori et al., 2011).

Kynurenine and KYNA have been implicated in various pain processes (Heyliger et al., 1998; Cosi et al., 2011; Párdutz et al., 2012; Pineda-Farias et al., 2013; Vécsei et al., 2013). KYNA can also induce antinociception in a dose-dependent manner by intrathecal administration in the von Frey test (Tuboly et al., 2015) and enhance the acute antinociceptive effects of morphine when co-administered (Morgan et al., 2009). The opioid system - where morphine acts - is well known for its crucial role in pain relief. The system is composed of three opioid receptors, namely mu, kappa and delta (MOP, KOP and DOP) and a series of endogenous opioid peptides. Opioid receptors belong to the G-protein coupled receptor (GPCR) superfamily and they are mostly coupled to $\mathrm{G}_{\mathrm{i} / \mathrm{o}}$ type G-proteins. Activation of these receptors leads to the inhibition of adenylyl cyclase which causes hyperpolarisation in the cell and inhibits the release of certain neurotransmitters (for review see Burford et al., 2000; Benyhe et al., 2015). Opioid receptors are expressed in the gastrointestinal tract, spinal cord and in high quantity in the cortical and striatal regions of the brain (Corbett et al., 2006). 
In our earlier paper, we reported that KYNA and KYNA1 (Fig. 1B) - a structural analogue (also known as SZR72) with considerable blood-brain barrier (BBB) permeability (Nagy et al., 2011) - did not bind directly to any opioid receptor, but after chronic administration they caused significant changes in receptor function in the cortex and striatum of mice (Zádor et al., 2014). Our hypothesis regarding to these effects was that KYNA and KYNA1 may alter opioid receptor function through the co-localized NMDA receptor.

In this study for the first time we investigated the acute effect of KYNA and KYNA1 on opioid receptor function together with the possible involvement of the NMDA receptor. Rats were acutely treated with a single dose of KYNA or KYNA1 intraperitoneally (i.p.) alone or in combination with the NMDA receptor antagonist MK-801. Additionally, KYNA and KYNA1 plasma and cerebrospinal fluid (CSF) concentration was measured after acute administration. Finally, isolated rat brain slices were treated in vitro with KYNA, KYNA1 and MK-801, to exclude the BBB and the peripheral metabolisation of KYNA and KYNA1, etc.). Samples from the cortex and striatum were investigated in opioid receptor mediated G-protein functional studies, similarly to our previous study (Zádor et al., 2014). 


\section{MATERIALS AND METHODS}

\subsection{Chemicals}

The MOR specific agonist enkephalin analogue Tyr-D-Ala-Gly-(NMe)Phe-Gly-ol (DAMGO) and the KOR agonist peptide dynorphin 1-13 were purchased from Bachem Holding AG (Bubendorf, Switzerland). The structurally modified DOR specific deltorphin II derivative, Ile ${ }^{5,6}$ deltorphin II was synthesized in the Laboratory of Chemical Biology of the Biological Research Centre (BRC, Szeged, Hungary). Acetonitrile and perchloric acid was purchased from Scharlau (Barcelona, Spain), acetic acid was purchased from VWR International (Radnar, PA, USA). EGTA, Tris-HCl, $\mathrm{MgCl}_{2}$ x $6 \mathrm{H}_{2} \mathrm{O}, \mathrm{NaCl}, \mathrm{KCl}, \mathrm{NaHPO}_{4}, \mathrm{NaHCO}_{3}, \mathrm{CaCl}_{2}, \mathrm{MgSO}_{4}, \mathrm{D}-$ glucose, GDP, the GTP analogue GTP $\gamma$ S, kynurenic acid (KYNA), MK-801 hydrogen maleate (NMDA receptor blocker) and 3-nitro-L-tyrosine (3-NLT) were obtained from Sigma-Aldrich (St. Louis, MO, USA). The KYNA analogue, KYNA1 was synthesized in the Department of Pharmaceutical Chemistry, University of Szeged. The radiolabeled GTP analogue, $\left[{ }^{35} \mathrm{~S}\right] \mathrm{GTP} \gamma \mathrm{S}$ (specific activity: $3.7 \times 10^{13} \mathrm{~Bq} / \mathrm{mmol} ; 1000 \mathrm{Ci} / \mathrm{mmol}$ ) was purchased from Hartmann Analytic (Braunschweig, Germany). For dissolving all ligands in receptor assays highly pure distilled water was used and they were stored in $1 \mathrm{mM}$ stock solution at $-20^{\circ} \mathrm{C}$.

\subsection{Animals and treatments}

\subsubsection{Animals}

For in vivo experiments 64 male Sprague-Dawley rats were used and 20 for in vitro with average body weights of $300 \mathrm{~g}$. The animals were bred and maintained under laboratory conditions on a 12-h dark 12-h light cycle at $22-24{ }^{\circ} \mathrm{C}$ and $\sim 65 \%$ relative humidity in the animal house of the Department of Neurology, Faculty of Medicine, University of Szeged (Szeged, Hungary). All 
experimental procedures were carried out in accordance with the European Communities Council Directive (2010/63/EU), and the Hungarian Act for the Protection of Animals in Research (XXVIII.tv. 32.§).

\subsubsection{In vivo animal treatments}

All animals for the in vivo experiments received a single intraperitoneal (i.p.) injection. The animal treatments are summarized in Figure 1, together with the main steps following treatments. One set of animals was divided into 7 groups as follows: (1) control (saline), (2) KYNA1 (296 mg/kg), and (3) KYNA (189 mg/kg) (4) MK-801 (1 mg/kg) + KYNA1 (296 mg/kg), (5) MK-801 (1 mg/kg) + KYNA (189 mg/kg), that each group was included 5 animals (KYNA1 and KYNA doses were equimolar, $1 \mathrm{mmol}$ ). These sets of animals were decapitated 30 minutes after the treatments (Fig. 1A). Additionally, two further groups containing 3 animals per group were set up receiving only a single i.p. MK-801 $(1 \mathrm{mg} / \mathrm{kg})$ injection. One of the group of animals was decapitated 15 minutes, while the other group of animals were decapitated 45 minutes after the treatment. These two groups were representing a control for the combined treatments to examine the effect of MK-801 per se on the opioid system prior to the administration (15 minutes) and right after reaching the peak plasma concentration of KYNA/KYNA1 (15+30 minutes, see the next paragraph) (Fig. 1A). The other set of animals was divided into 5 groups: (1) control (saline), (2) KYNA (189 mg/kg) and (3) KYNA1 (296 mg/kg), (4) MK-801 (1 mg/kg) + KYNA (189 mg/kg), (5) MK-801 (1 mg/kg) + KYNA1 (296 mg/kg). Groups (1)-(3) contained 7, while groups (4) and (5) contained 6 animals per group. These sets of animals were sacrificed 2 hours after treatments (Fig. 1B). In the case of combined treatments MK-801 was administered to the animals 15 minutes prior to KYNA and KYNA1 treatment, in this way NMDA receptors will be already blocked by MK-801 when KYNA and KYNA1 are administered. 
The chosen time phases for decapitation (30 minutes and 2 hours) were based on previously measured plasma concentration (yet unpublished data) of KYNA and KYNA1 after their i.p. administration: 30 minutes after injection the plasma concentrations of KYNA/KYNA1 was the highest, while after 2 hours it was the lowest.

After the treatments, animals were anesthetized at the appropriate time points by chloral hydrate (Fig. 1). Those sets of animals which were anesthized 30 minutes after saline, KYNA1 or KYNA alone treatments, the cerebrospinal fluid (CSF) and blood samples were collected immediately afterwards for KYNA and KYNA1 concentration analysis (see later 2.3) (Fig. 1A). This was followed by cardiac perfusion of the animals using 0.1M PBS and finally the animals were decapitated (Fig. 1). After decapitation the perfused brains were removed, and the entire striatum together with the overlying cortex were excised (Fig. 1). Samples then were stored at -80 ${ }^{\circ} \mathrm{C}$ until membrane homogenate preparation. 


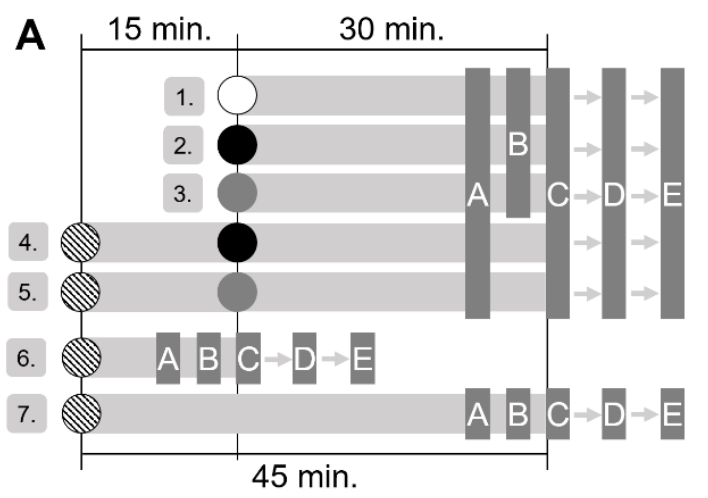

Figure symbols:

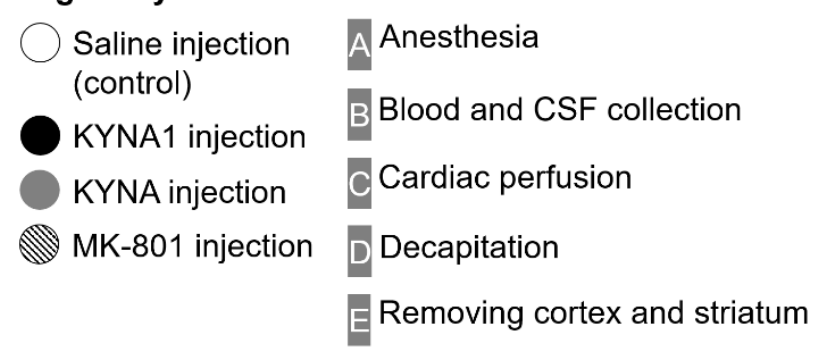

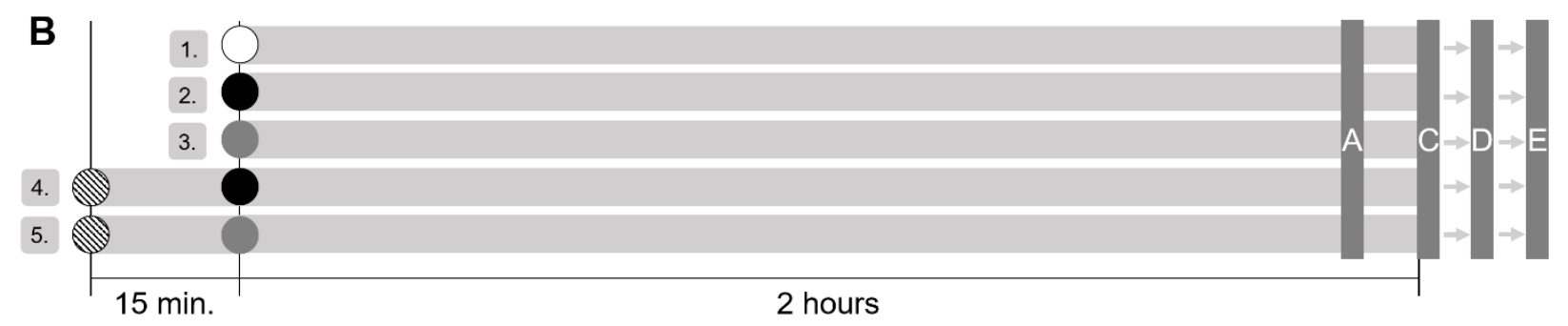

Figure 1. Animal treatments, groups, treatment duration times and main steps following the injections. A: Represents group 1-5 in which the animals were sacrificed 30 minutes after KYNA/KYNA1 treatment together with group 6 and 7 where animals received a single MK-801 injection and sacrificed 15 and 45 minutes after treatment. B: Represents group 1-5 in which the animals were sacrificed 2 hours after KYNA/KYNA1 treatment. Circles and grey rectangulars marked with letters (A-E) represent the injection timepoints and the steps following treatmens, respectively. For additional information see under sections 2.2.2 and 2.2.1. 


\subsubsection{In vitro isolated rat cortex and striatum treatments in isolated organ baths}

The in vitro studies were performed in isolated organ baths using 3 animals for each group (control, KYNA, KYNA1 and MK-801 treatment groups). After decapitation, brains were removed immediately in less than 30 seconds and placed it at $36-37^{\circ} \mathrm{C}$ (physiological rat body temperature) artificial cerebrospinal fluid (ACSF, consisted of $130 \mathrm{mM} \mathrm{NaCl}, 3.5 \mathrm{mM} \mathrm{KCl}, 1 \mathrm{mM}$ $\mathrm{NaH}_{2} \mathrm{PO}_{4}, 24 \mathrm{mM} \mathrm{NaHCO}_{3}, 3 \mathrm{mM} \mathrm{CaCl}_{2}, 1.5 \mathrm{mM} \mathrm{MgSO}_{4}$ and $10 \mathrm{mM}$-glucose) supplied with oxygen. Afterwards the striatum and cortex were quickly separated and transferred to the isolated organ bath chambers containing $10 \mathrm{ml}, 37^{\circ} \mathrm{C}$ ACSF with oxygen supply. Cortex and striatum slices were incubated for 30 minutes. After the incubation period KYNA, KYNA1 or MK-801 were added to the bath for 30 minutes. The concentrations for KYNA and KYNA1 was $200 \mu \mathrm{M}$ and for MK-801 it was $50 \mu \mathrm{M}$ (Füvesi et al., 2004). Samples then were stored at $-80{ }^{\circ} \mathrm{C}$ until for the cell membrane preparation (see under 2.4.1).

\subsection{Detection of KYNA and KYNA1 concentration in plasma and CSF with HPLC}

\subsubsection{Sample preparation}

Animals that were sacrificed 30 minutes after the in vivo treatments (see 2.2.2) the CSF was taken quickly from the suboccipital cistern of rats with 23G needle to Eppendorf tubes (rats were anaesthetized and they were taken to the stereotaxic setup in order to fix their head). After collection the CSF samples were stored at $-80^{\circ} \mathrm{C}$ until use for concentration detection of KYNA or KYNA1. After collecting the CSF, blood samples were collected immediately from the left ventricle into the cool, EDTA containing tubes and centrifuged at $12,000 \mathrm{rpm}$ for $10 \mathrm{~min}$ at $4{ }^{\circ} \mathrm{C}$. The serum samples for KYNA1 concentration detection were collected and stored at $-80^{\circ} \mathrm{C}$ until use. 
The serum samples for KYNA concentration detection were thawed and, after a brief vortex, the serum sample was 'shot' to a precipitation solvent (containing PCA with 3-NLT as internal standard, with resulting concentrations of $2.5 \mathrm{w} / \mathrm{w} \%$ and $2 \mu \mathrm{M}$, respectively). The samples were subsequently centrifuged at $12,000 \mathrm{rpm}$ for $10 \mathrm{~min}$ at $4{ }^{\circ} \mathrm{C}$, and the supernatants were collected for measurement. Additionally, control animals (saline treated) were also used to detect endogenous KYNA levels in the plasma.

\subsubsection{Chromatographic conditions for KYNA and KYNAI}

For the determination of KYNA1 from plasma and CNS and KYNA from CNS, a Thermo LCQFleet ion trap mass spectrometer was used equipped with an electrospray ionization (ESI) ion source combined with a Dionex Ultimate3000 HPLC system. The ionization parameters were as follows: heater temperature: $500^{\circ} \mathrm{C}$, sheath gas flow rate: 60 , auxiliary gas flow rate: 20 , spray voltage: $4 \mathrm{kV}$, capillary temperature: $400^{\circ} \mathrm{C}$. Chromatographic separations were performed on an

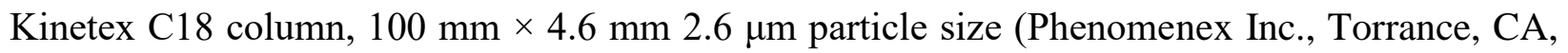
USA ) after passage through a SecurityGuard pre-column C18, 4 x 3.0 mm I.D., $5 \mu \mathrm{m}$ particle size (Phenomenex Inc., Torrance, CA, USA ) with a mobile phase composition of $0.05 \%$ aqueous $\mathrm{CH}_{3} \mathrm{COOH} / \mathrm{ACN}=90 / 10(\mathrm{v} / \mathrm{v})$, applying isocratic elution. The flow rate and the injection volume were $1 \mathrm{ml} / \mathrm{min}$ and $50 \mu \mathrm{l}$, respectively.

The KYNA concentrations of the serum samples were quantified on the basis of the method of Herve et al. (1996). Briefly, we used an Agilent 1100 HPLC system (Agilent Technologies, Santa Clara, CA, USA) equipped with fluorescence and a UV detector; the former was applied for the determination of KYNA and the latter for the determination of the internal standard (3-NLT). Chromatographic separations were performed on a Kinetex C18 column, 150 mm x 4.6 mm I.D., 
$5 \mu \mathrm{m}$ particle size (Phenomenex Inc., Torrance, CA, USA) after passage through a Security Guard pre-column C18, 4 x 3.0 mm I.D., $5 \mu \mathrm{m}$ particle size (Phenomenex Inc., Torrance, CA, USA) with a mobile phase composition of $0.2 \mathrm{M}$ zinc acetate/ACN $=95 / 5(\mathrm{v} / \mathrm{v})$, the $\mathrm{pH}$ of which was adjusted to 6.2 with acetic acid, applying isocratic elution. The flow rate was $1 \mathrm{ml} / \mathrm{min}$ and the injection volume was $20 \mu 1$. The fluorescence detector was set at excitation and emission wavelengths of 344 and $398 \mathrm{~nm}$. The UV detector was set at a wavelength of $365 \mathrm{~nm}$. The LOD and LLOQ for KYNA in the plasma samples were $1 \mathrm{nM}$ and $3.75 \mathrm{nM}$, the relative standard deviation was $\leq 2.2 \%$ for the peak area response and $\leq 0.1 \%$ for the retention time for KYNA and the recoveries ranged from 103 to $108 \%$ for KYNA.

\subsection{G-protein activity assay}

\subsubsection{Cortex and striatum membrane preparations}

The membrane fractions of rat cortex and striatum for $\left[{ }^{35} \mathrm{~S}\right] \mathrm{GTP} \gamma \mathrm{S}$ binding experiments were prepared after cardiac perfusion and the decapitation of the animals. Briefly, the cortex and striatum were collected and homogenized on ice in $50 \mathrm{mM}$ Tris-HCl, $1 \mathrm{mM}$ EGTA and $5 \mathrm{mM}$ $\mathrm{MgCl}_{2}$ buffer (TEM, pH 7.4) with a teflon-glass homogenizer (potter homogenizer). Protein content for the assay was $10 \mu \mathrm{g} / \mathrm{ml}$ and stored at $-80{ }^{\circ} \mathrm{C}$ until use.

\subsubsection{Functional $\left[{ }^{35} S\right] G T P \gamma S$ binding assays}

The assays were performed according to previous reports, with slight modifications (Traynor \& Nahorski, 1995; Sim \& Childers, 1997) Membrane fractions of rat cortex and striatum were incubated in a final volume of $1 \mathrm{ml}$ at $30{ }^{\circ} \mathrm{C}$ for $60 \mathrm{~min}$ in Tris-EGTA buffer (pH 7.4) composed of $50 \mathrm{mM}$ Tris- $\mathrm{HCl}, 1 \mathrm{mM}$ EGTA, $3 \mathrm{mM} \mathrm{MgCl} 2,100 \mathrm{mM} \mathrm{NaCl}$, containing 20 $\mathrm{MBq} / 0.05 \mathrm{~cm}^{3}\left[{ }^{35} \mathrm{~S}\right] \mathrm{GTP} \gamma \mathrm{S}(0.05 \mathrm{nM})$ together with increasing concentrations $\left(10^{-10}-10^{-5} \mathrm{M}\right)$ of 
DAMGO, dynorphin 1-13 or Ile ${ }^{5,6}$-deltorphin II. Total binding (T) was measured in the absence of the opioid ligands, non-specific binding (NS) was determined in the presence of $10 \mu \mathrm{M}$ unlabeled GTP $\gamma$ S and subtracted from total binding. The difference (T-NS) represents basal activity. Bound and free $\left[{ }^{35} \mathrm{~S}\right] \mathrm{GTP} \gamma \mathrm{S}$ were separated by vacuum filtration through Whatman GF/B filters with Brandel M24R Cell harvester. The filtration and washing procedure together with radioactivity detection was performed as reported previously (Zádor et al., 2014). The $\left[{ }^{35} \mathrm{~S}\right] \mathrm{GTP} \gamma \mathrm{S}$ binding experiments were performed in triplicates and repeated at least three times.

\subsection{Data analysis}

In the HPLC analysis, the peak area responses were plotted against the corresponding concentration, and the linear regression computations were carried out by the least square method with the freely available R software (R Core Team, 2014).

Experimental data of $\left[{ }^{35} \mathrm{~S}\right] \mathrm{GTP} \gamma \mathrm{S}$ binding assays were presented and analysed as previously described (Zádor et al., 2014). Stimulation was given as percentage of the specific $\left[{ }^{35} \mathrm{~S}\right] \mathrm{GTP} \gamma \mathrm{S}$ binding observed over the basal activity, which was settled as $100 \%$. In the figures dose-response curves, $\mathrm{E}_{\max }$ and/or $\log \mathrm{EC}_{50}$ values have been shown. The significance level was determined by using One-way ANOVA with Bonferroni's Multiple Comparison statistical analysis in GraphPad Prism 5.0. Significance was accepted at the $P<0.05$ level. 


\section{RESULTS}

\subsection{The effect of acute KYNA and KYNA1 treatment alone and with the combination of MK-801 on agonist-mediated opioid receptor G-protein activation in rat cortex and striatum}

Opioid agonist-stimulated G-protein activation was measured in $\left[{ }^{35} \mathrm{~S}\right] \mathrm{GTP} \gamma \mathrm{S}$ binding assays in cerebral cortex and striatum homogenates of saline (control) or KYNA/KYNA1-treated animals. MOP receptors were activated by the use of DAMGO. KOP receptor activation was measured in the presence of dynorphin (1-13), while DOP receptor stimulation was accomplished with Ile ${ }^{5,6}$-deltorphin II , a synthetic DOP receptor peptide agonist ligand. All opioid agonist ligands were applied in increasing concentrations to determine the maximum efficacy $\left(\mathrm{E}_{\max }\right)$ of the opioid receptors G-protein and ligand potency $\left(\mathrm{EC}_{50}\right)$. We also investigated the effect of NMDA receptor specific antagonist $\mathrm{MK}-801$ on opioid receptor activity alone and in the presence of KYNA and KYNA1 (combined treatments).

In the cortex area, $296 \mathrm{mg} / \mathrm{kg}$ KYNA1 treatment after 30 minutes significantly decreased the maximum efficacy of DAMGO at the MOP receptor, the reduction was nearly $50 \%(\mathrm{P}<0.001$, df: 6; Fig. 2A). This effect was slightly reversed by $1 \mathrm{mg} / \mathrm{kg}$ MK-801. $189 \mathrm{mg} / \mathrm{kg} \mathrm{KYNA}$ treatment alone and in combination with $1 \mathrm{mg} / \mathrm{kg}$ MK-801 did not change the MOP receptor mediated Gprotein activity (Fig. 2A). Interestingly $1 \mathrm{mg} / \mathrm{kg}$ MK-801 per se strongly reduced MOP receptor activity after 15 and 45 minutes in the cortex compared to control (both $\mathrm{P}<0.01$, df: 6; Fig. 2A) and after 45 minutes compared to KYNA treatment alone ( $\mathrm{P}<0.05$, df: 6; Fig. 2A). The potency of DAMGO was not altered in either treatment condition (data not shown).

Interestingly, 30 minutes KYNA1 treatment resulted an opposite effect in KOP receptor G-protein activity in the cortex compared to MOP receptor: the maximum efficacy of the KOP 
receptor significantly increased compared to control (P < 0.05, df: 6; Fig. 2B). This enhancement was reduced by MK-801 in the combined treatments, but the reduction was statistically not significant (Fig. 2B). KYNA did not alter KOP receptor maximum efficacy significantly, neither MK-801 in either treatment condition (Fig. 2B). The potency of the KOP receptor stimulator ligand dynorphin 1-13 was not altered by either KYNA, KYNA1 or MK-801, similarly to DAMGO (data not shown).

In contrast, the DOP receptor G-protein activity did not show any significant difference in the cortex area after 30 minutes KYNA and KYNA1 or 15 and 45 minutes MK-801 acute treatments (data not shown). However, the potency of the DOP receptor agonist Ile $e^{5,6}$-deltorphin II significantly enhanced after 30 minutes KYNA1 treatment, which was reversed to control level by MK-801 co-administered with KYNA1 (P < 0.01, df: 6; Fig. 2C).

In the striatum in case of MOP and KOP receptor maximum G-protein efficacy was reduced by 30 minutes KYNA (MOP receptor: $\mathrm{P}<0.01$, KOP receptor: $\mathrm{P}<0.001$, df: 6; Fig. 2D and E), KYNA1 treatments (both receptors: P < 0.001, df: 6, Fig. 2D and E) and also both (15 and 45 minutes) MK-801 treatments alone (MOP and KOP receptor, 15 and 45 min.: $\mathrm{P}<0.001$, df: 6; Fig.2D and E). MK-801 in combination with KYNA1 and KYNA did not cause any significant alterations in G-protein activity compared to their treatments alone in MOP receptor (Fig. 2D). In case of KOP receptor co-administering MK-801 resulted a noticeable increase in the $\mathrm{E}_{\max }$ values compared to KYNA1 and KYNA alone, although the difference was not significant (Fig. 2E). Interesting to note, that KYNA1 treatment alone reduced KOP receptor G-protein activity more effectively than the 15 and 45 minutes MK-801 treatment (15 and 45 min.: P $<0.05$, df: 6; Fig. 2E). In the DOP receptor only 30 minutes KYNA and 45 minutes MK-801 treatments caused a significant reduction with a similar degree in the receptors G-protein activity $(\mathrm{P}<0.01$, df: 6; Fig. 
2F). Additionally, in the striatum neither of the potency of the opioid receptor selective agonist ligands was altered significantly by KYNA1, KYNA or MK-801 (data not shown).

After 2 hour treatment of KYNA1 and KYNA, no significant changes were observed in either of the opioid receptors G-protein activity or ligand potency regardless of the brain areas (data not shown). Thus, in summary, KYNA1 and KYNA was only effective 30 minutes after the injection, and the alterations were opposite depending on the brain area and opioid receptor (Table $1)$. 

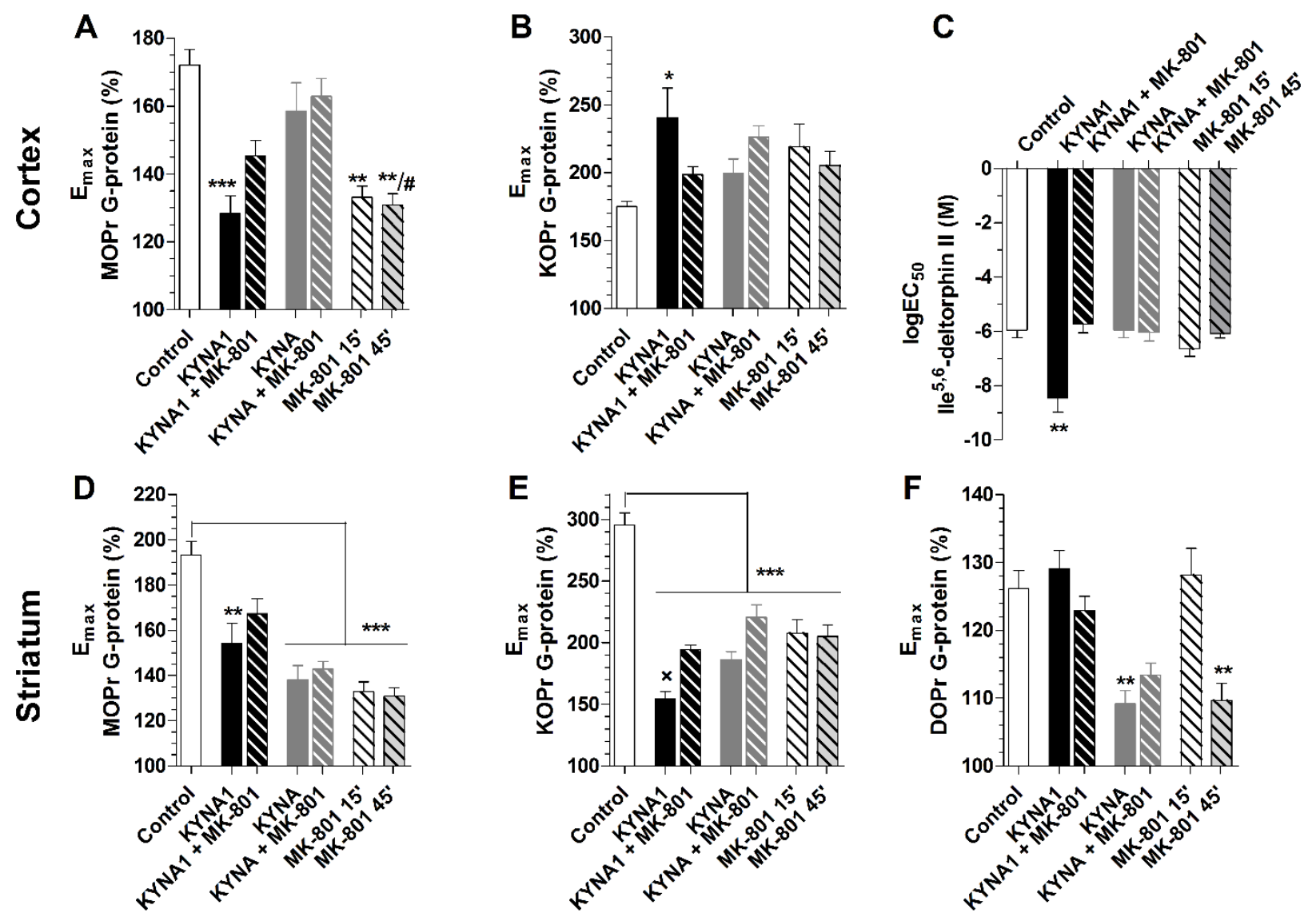

Figure 2. The acute (30 min, in vivo) effect of KYNA, KYNA1 alone and in combination with MK-801 on agonist-stimulated opioid receptor G-protein activity in $\left.{ }^{35} \mathrm{~S}\right] \mathrm{GTP} \gamma \mathrm{S}$ binding assays performed in rat cortex (A-C) and striatum (D-F). Each animal received a single i.p. injection of $296 \mathrm{mg} / \mathrm{kg}$ KYNA1 or $189 \mathrm{mg} / \mathrm{kg}$ KYNA dosage, while MK-801 was administered in $1 \mathrm{mg} / \mathrm{kg}$ i.p., as described in section 2.2.2. A, B and D-F represents the maximal efficacy $\left(E_{\max }\right)$ over basal activity $(100 \%)$ of MOP and KOP receptors G-protein in cortex (A and B) and striatum (D and $\mathbf{E}$ ) and of DOP receptor G-protein in striatum (F), respectively. C represents the potency $\left(\operatorname{logEC} \mathrm{C}_{50}\right)$ of the DOR specific agonist Ile ${ }^{5,6}$-deltorphin II. Columns represent means \pm S.E.M. for at least three experiments performed in triplicate. The calculation of $\mathrm{E}_{\max }$ and $\mathrm{EC}_{50}$ values can be seen under section 2.5. *: indicates the significance level of $\mathrm{E}_{\max }$ and $\log \mathrm{EC}_{50}$ values compared to control. \#: indicates the significance level of $\mathrm{E}_{\max }$ values compared to KYNA treatment alone. $\times$ : indicates the significant reduction of $E_{\max }$ value after KYNA1 injection per se compared to MK-801 15 and 45 minutes treatment alone. One-way ANOVA with Bonferroni's Multiple Comparison was used for statistical analysis. ***: $\mathrm{P}<0.001$, **: $\mathrm{P}<0.01$, $* / \# / \times: \mathrm{P}<0.05$. 
Table 1. Summary and comparison of acute in vivo effect KYNA, KYNA1 and MK-801 treatment on opioid receptors mediated G-protein activity and ligand potency.

\begin{tabular}{|c|c|c|c|c|c|c|c|c|c|}
\hline & & \multicolumn{2}{|c|}{ KYNA (30') } & \multicolumn{2}{|c|}{ KYNA1 (30') } & \multicolumn{2}{|c|}{ MK-801 (15') } & \multicolumn{2}{|c|}{ MK-801 (45') } \\
\hline & & $\begin{array}{l}\text { G-protein } \\
\text { efficacy }\end{array}$ & $\begin{array}{l}\text { Ligand } \\
\text { potency }\end{array}$ & $\begin{array}{c}\text { G-protein } \\
\text { efficacy }\end{array}$ & $\begin{array}{l}\text { Ligand } \\
\text { potency }\end{array}$ & $\begin{array}{c}\text { G-protein } \\
\text { efficacy }\end{array}$ & $\begin{array}{l}\text { Ligand } \\
\text { potency }\end{array}$ & $\begin{array}{c}\text { G-protein } \\
\text { efficacy }\end{array}$ & $\begin{array}{l}\text { Ligand } \\
\text { potency }\end{array}$ \\
\hline \multirow{2}{*}{ MOR } & Ctx. & $\varnothing$ & $\varnothing$ & $\downarrow$ & $\varnothing$ & $\downarrow$ & $\varnothing$ & $\downarrow$ & $\varnothing$ \\
\hline & Str. & $\varnothing$ & $\varnothing$ & $\downarrow$ & $\varnothing$ & $\downarrow$ & $\varnothing$ & $\downarrow$ & $\varnothing$ \\
\hline \multirow{2}{*}{ KOR } & Ctx. & $\varnothing$ & $\varnothing$ & $\uparrow$ & $\varnothing$ & $\varnothing$ & $\varnothing$ & $\downarrow$ & $\varnothing$ \\
\hline & Str. & $\downarrow$ & $\varnothing$ & $\downarrow$ & $\varnothing$ & $\downarrow$ & $\varnothing$ & $\downarrow$ & $\varnothing$ \\
\hline \multirow{2}{*}{ DOR } & Ctx. & $\varnothing$ & $\varnothing$ & $\varnothing$ & $\uparrow$ & $\varnothing$ & $\varnothing$ & $\varnothing$ & $\varnothing$ \\
\hline & Str. & $\downarrow$ & $\varnothing$ & $\varnothing$ & $\varnothing$ & $\varnothing$ & $\varnothing$ & $\downarrow$ & $\varnothing$ \\
\hline
\end{tabular}

Ctx.: cortex, Str.: striatum, $\uparrow:$ significant enhancement, $\downarrow$ : significant inhibition, $\varnothing$ : no significant effect. 


\subsection{KYNA and KYNA1 plasma and CSF concentrations after 30 minutes administration}

Since the opioid receptor G-protein activity in the cortex and striatum was only altered after 30 minutes of KYNA1 and KYNA treatment, we measured the concentration of these two compounds in the cerebrobrospinal fluid (CSF) and compared it to their concentration in the blood plasma. The treatment conditions were the same as described in section 2.2.2. Additionally, the endogenous KYNA plasma concentration was also determined for control. KYNA1 and KYNA CSF and plasma concentrations were measured by HPLC.

30 minutes following KYNA treatment the concentration of KYNA dramatically increased compared to endogenous KYNA plasma concentrations as expected ( $\mathrm{P}<0.001$, df: 4; Fig. 3). It reached to $630 \mu \mathrm{M}$ in the plasma (endogenous KYNA plasma concentration: $0.2 \mu \mathrm{M}$ ), while this was reduced to $48 \mu \mathrm{M}$ in the CSF ( $\mathrm{P}<0.001$, df: 4; Fig. 3). KYNA1 displayed a significantly lower, $124 \mu \mathrm{M}$ concentration in the plasma compared to KYNA (P < 0.001, df: 4; Fig. 3), and 65 $\mu \mathrm{M}$ in the $\mathrm{CSF}$. 


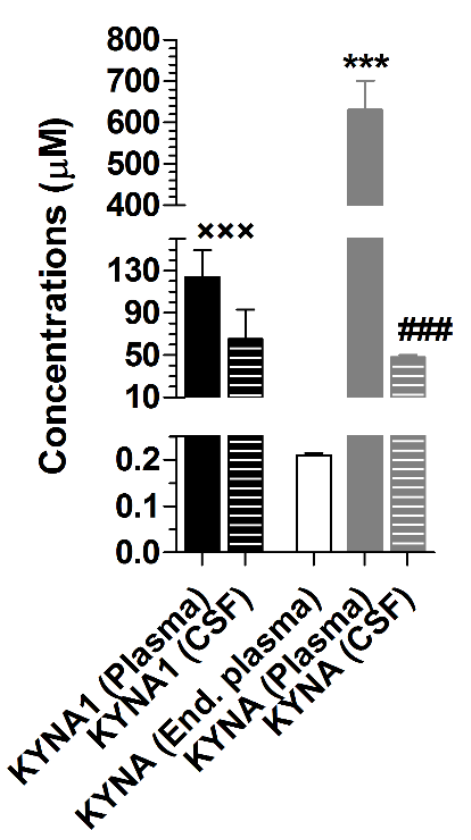

Figure 3. The blood plasma and CSF concentration levels of KYNA1 and KYNA after 30 minutes of $296 \mathrm{mg} / \mathrm{kg}$ (KYNA1) and $189 \mathrm{mg} / \mathrm{kg}$ (KYNA) acute administration of the compounds. Additionally, the endogenous KYNA plasma concentrations (End. plasma) is also indicated for the control. For further information regarding to animal treatments and HPLC analysis see under section 2.2.2 and 2.3, respectively). Columns represent means \pm S.E.M. for at least three experiments. *: indicates the significant increase in concentrations of KYNA after treatment compared to endogenous KYNA levels in the plasma. \#: indicates the significant decrease of KYNA CSF concentration levels compared to plasma after treatment. $\times$ : indicates the significant difference between KYNA and KYNA1 plasma concentration levels. One-way ANOVA with Bonferroni's Multiple Comparison was used for statistical analysis. ***/\#\#\#: P < 0.001 . 


\subsection{The effect of in vitro administered KYNA1, KYNA and MK-801 on agonist-mediated opioid receptor G-protein activation in the isolated rat cortex and striatum slices}

In these studies freshly prepared brain slices of rat striatum and cortex were prepared and treated with KYNA, KYNA1 and MK-801 in an isolated organ bath. Following 30 min incubation tissue specimens were further processed by homogenisation for G-protein activity studies as described earlier (section 2.4.1). MOP, KOP and DOP G-protein activity was measured the same way as in in vivo studies (see section 2.4.2).

In the in vitro studies of isolated cortex slices, the maximum G-protein activity of MOP receptor significantly decreased nearly $60 \%$ in the cortex after $200 \mu \mathrm{M}$ KYNA1 treatment $(\mathrm{P}<$ 0.001, df: 3), which was significantly lower compared to the reducing effect of $200 \mu \mathrm{M}$ KYNA (P $<0.001$, df: 3; Fig. 4A). The results in $50 \mu$ M MK-801 treated cortex were very similar to KYNA1 treated samples, the reduction reached $70 \%$ (P<0.001, df: 3; Fig. 4A). The potency of DAMGO on MOP receptor was not altered after either in vitro treatments (data not shown). Similar results were observed in KOP receptor G-protein maximum activity in the cortex after KYNA1 and MK801 treatments, but the inhibitory effects were much more prominent in both cases $(\mathrm{P}<0.001$, df: 3; Fig. 4B). Interestingly, KYNA did not alter the maximum activity of KOP receptor in the cortex (Fig. 4B) and similarly to MOP receptor agonist, the potency of the KOP receptor agonist ligand (dynorphin 1-13) remained unaltered after in case of all in vitro treatments (data not shown). The DOP receptor G-protein activity was reduced significantly after KYNA, KYNA1 and MK-801 treatments as well (P < 0.001, df: 3; Fig. 4C), moreover the ligand potency of Ile ${ }^{5,6}$-deltorphin II was increased after KYNA1 treatment (P < 0.05, df: 3; Fig. 4D).

In the striatum the in vitro treatments showed very similar results compared to cortex. For all three opioid receptor G-protein activity was reduced by all three compounds compared to 
control. MOP and KOP receptor G-protein activity was reduced in a similar extent by the compounds and compared to the cortex (KYNA1: $\mathrm{P}<0.001$, KYNA: $\mathrm{P}<0.05, \mathrm{MK}-801$ : $\mathrm{P}<$ 0.001, df: 3; Fig. 4E and F). In case of DOP receptors the reduction was less robust than in the cortex region, but KYNA reduced the $\mathrm{E}_{\max }$ value with comparable extent to KYNA1 and MK-801 similarly to the cortex (KYNA1: P < 0.01, KYNA: P < 0.05, MK-801: P < 0.05, df: 3; Fig. 4G). The main difference in the striatum is that the DOP receptor agonist potency was not altered by either compound (data not shown). Additionally, KYNA1 and MK-801 reduced MOP and KOP receptor maximum G-protein efficacy more effectively than KYNA (P < 0.001, df: 3; Fig. 4E and F).

In summary the in vitro treatments displayed a reducing effect in receptor G-protein signaling regardless of the opioid receptor type and brain region (except for KYNA in KOP receptor) (Table 2). Also the levels of inhibition were very similar in the two brain regions within the opioid receptor types. Additionally, KYNA1 and MK-801 displayed stronger effects than KYNA in case of MOP and KOP receptor in both cortex and striatum. 

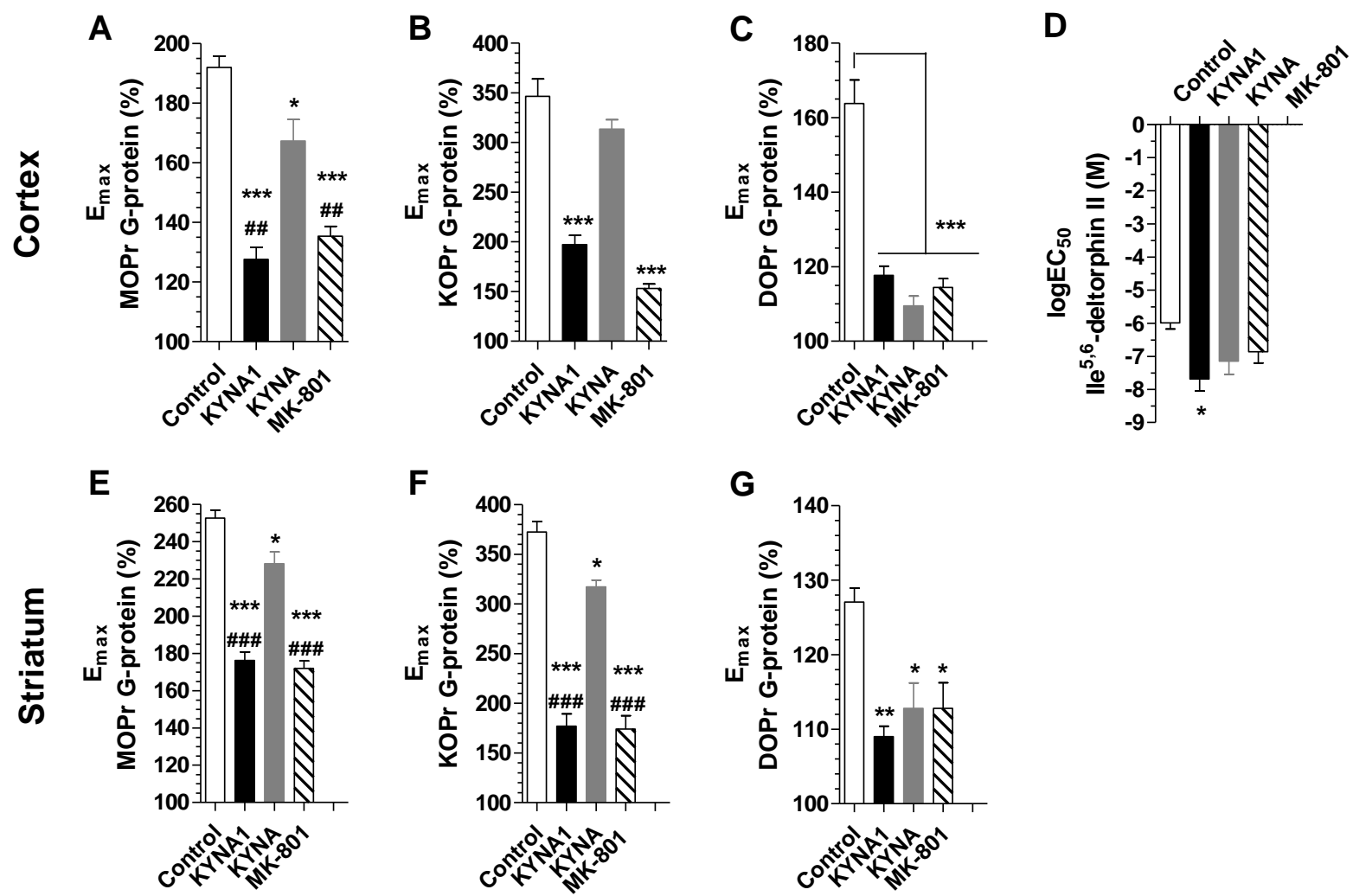

Figure 4. Agonist-stimulated opioid receptor G-protein activity in $\left.{ }^{35} \mathrm{~S}\right] \mathrm{GTP} \gamma \mathrm{S}$ binding assays performed in rat cortex (A-D) and striatum (E-G) homogenised brain slices after acute in vitro treatment of KYNA1, KYNA and MK 801. KYNA1 and KYNA were administered on cortex and striatum brain slices in $200 \mu \mathrm{M}$, while $\mathrm{MK} 801$ in $50 \mu \mathrm{M}$ concentrations. Samples were treated for 30 minutes in isolated organ baths as described in section 2.2.3. A-C and E-G represents the maximal efficacy ( $\left.E_{\max }\right)$ over basal activity (100\%) of MOP, KOP and DOP receptors G-protein in cortex (A-C) and striatum (E-G). D represents the potency $\left(\log \mathrm{EC}_{50}\right)$ of the DOR specific agonist Ile ${ }^{5,6}$-deltorphin II. Columns represent means \pm S.E.M. for at least three experiments performed in triplicate. The calculation of $\mathrm{E}_{\max }$ and $\mathrm{EC}_{50}$ values is discussed under section 2.5. *: indicates the significance level of $\mathrm{E}_{\max }$ and $\operatorname{logEC} \mathrm{C}_{50}$ values compared to control. \#: indicates the significance level of $E_{\max }$ values of KYNA1 and MK-801 compared to KYNA. One-way ANOVA with Bonferroni's Multiple Comparison was used for statistical analysis. $* * *: \mathrm{P}<0.001, * *: \mathrm{P}<0.01, *: \mathrm{P}<0.05$. 
Table 2. Summary and comparison of acute $\underline{\text { in vitro }}$ effect KYNA, KYNA1 and MK-801 treatment on opioid receptors mediated G-protein activity and ligand potency.

\begin{tabular}{|c|c|c|c|c|c|c|c|}
\hline & & \multicolumn{2}{|c|}{ KYNA } & \multicolumn{2}{|c|}{ KYNA1 } & \multicolumn{2}{|c|}{ MK-801 } \\
\hline & & $\begin{array}{l}\text { G-protein } \\
\text { efficacy }\end{array}$ & $\begin{array}{l}\text { Ligand } \\
\text { potency }\end{array}$ & $\begin{array}{l}\text { G-protein } \\
\text { efficacy }\end{array}$ & $\begin{array}{l}\text { Ligand } \\
\text { potency }\end{array}$ & $\begin{array}{l}\text { G-protein } \\
\text { efficacy }\end{array}$ & $\begin{array}{l}\text { Ligand } \\
\text { potency }\end{array}$ \\
\hline \multirow{2}{*}{ MOR } & Ctx. & $\downarrow$ & $\varnothing$ & $\downarrow$ & $\varnothing$ & $\downarrow$ & $\varnothing$ \\
\hline & Str. & $\downarrow$ & $\varnothing$ & $\downarrow$ & $\varnothing$ & $\downarrow$ & $\varnothing$ \\
\hline \multirow{2}{*}{ KOR } & Ctx. & $\varnothing$ & $\varnothing$ & $\downarrow$ & $\varnothing$ & $\downarrow$ & $\varnothing$ \\
\hline & Str. & $\downarrow$ & $\varnothing$ & $\downarrow$ & $\varnothing$ & $\downarrow$ & $\varnothing$ \\
\hline \multirow{2}{*}{ DOR } & Ctx. & $\downarrow$ & $\varnothing$ & $\downarrow$ & $\uparrow$ & $\downarrow$ & $\varnothing$ \\
\hline & Str. & $\downarrow$ & $\varnothing$ & $\downarrow$ & $\varnothing$ & $\downarrow$ & $\varnothing$ \\
\hline
\end{tabular}

Ctx.: cortex, Str.: striatum, $\uparrow:$ significant enhancement, $\downarrow$ : significant inhibition, $\varnothing$ : no significant effect. 


\section{DISCUSSION}

In this study we have shown for the first time that KYNA1 and KYNA not only alters opioid receptor function after chronic treatment as showed previously (Zádor et al., 2014), but also after acute administration in a tissue and receptor specific way. Moreover, the effects were modified by MK-801, a selective NMDA receptor antagonist, indicating that the changes might be mediated through this receptor. The effects seen in vivo were found also in acute in vitro experiments in isolated cortex and striatum slices. Our results further support previous findings showing the effect of KYNA on the opioid receptors activity (Marek et al., 1991; Kekesi et al., 2002; Horvath et al., 2007; Mecs et al., 2009; Morgan et al., 2009; Safrany-Fark et al., 2015).

When compared the results of chronic (128 and $200 \mathrm{mg} / \mathrm{kg} / \mathrm{day}$, i.p., for 9 days) and acute treatments, the data accords just in few cases (DOP receptor in cortex and striatum and KOP receptor in striatum by KYNA treatment). In the other cases, the effects were opposite (KYNA1 treatment on KOP receptor in the striatum), or it did not cause any significant alterations when compared to the appropriate acutely treated group (KYNA1 on MOP receptor). Nevertheless, the molecular mechanisms behind these effects might be due to altered opioid receptor G-protein gene or protein expression or receptor sensitivity, which is most probably mediated through KYNA/KYNA1 specific receptors since they do not bind directly to opioid receptors (Zádor et al., 2014). The NMDA receptor has been demonstrated to bind KYNA - although with low micromolar affinity (Stone, 1993) - also, the interaction of NMDA and opioid receptors have been demonstrated in many levels (Mao, 1999). Morevoer, a functional interaction and co-localization has been described between the MOP receptor and NMDA receptor in the NAcc shell - which is part of the ventral striatum - with electrophysiological (Martin et al., 1997) and anatomical studies (Hiller et al., 1994) and with immunocytochemical labeling (Gracy \& Pickel, 1996; Svingos et al., 
1996; Gracy et al., 1997). Thus in order to investigate the possible role of the NMDA receptor we applied MK-801 (also known as dizocilpine) (Wong et al., 1986), a highly NMDA receptor selective antagonist (Kornhuber et al., 1989; Koek et al., 1993). MK-801 has also been demonstrated to alter opioid receptor-mediated effects (Kotlińska, 2001; Morgan et al., 2009), however it does not bind directly to opioid receptors (Koek et al., 1993) similarly to KYNA.

MK-801 alone behaved similarly as KYNA1 or KYNA (Fig. 2A and D). MK-801 in combination with KYNA1 or KYNA displayed a somewhat less pronunced reduction opioid receptor G-protein activity in certain groups (KYNA1+MK-801: Fig. 2A and D; KYNA+MK801: Fig. 2F) compared to KYNA1 or MK-801 alone. The results might be explained by the impairment of KYNA1/KYNA and MK-801 individual activity when administered together, since they exerted similar effects alone, indicating an NMDA receptor mediated effect. The same explanation arises in case of MOP and KOP receptors expressed in the striatum, where KYNA and MK-801 alone or in combination reduced G-protein signaling (Fig. 2D and E). In case of DOP receptor in the cortex, the enhanced agonist (Ile $\mathrm{I}^{5,6}$-deltorphin II ) ligand potency followed by 30 minutes KYNA1 treatment was reduced to control levels by MK-801 pretreatment (Fig. 2C). Interestingly, MK-801 alone did not cause any alterations in ligand potency following 15 or 45 minute administration (Fig. 2C), which indicates that MK-801 inhibited the effect of KYNA1 through NMDA receptor. Furthermore, it also shows that the enhanced DOP receptor agonist ligand potency is a KYNA1 specific action, whereas the attenuated opioid receptor G-protein activity in the cortex (MOP and DOP receptor) and striatum (all three opioid receptors) are also MK-801 related.

AMPA and kainate receptors are also a direct targets for KYNA and there is evidence that they can also interact with opioid receptors. Their interactions have been studied mainly in terms 
of opioid addiction and has been described so far in the amygdala and hippocampus (Kam et al., 2010; Scavone et al., 2011), which are outside the point of our examined brain regions. To the best of our knowledge there are no current studies so far describing AMPA/kainate-opioid receptor interactions in the striatum or cortex. However, it does not exclude the possibility and may be an alternative mechanism which through KYNA/KYNA1 alters opioid receptor function.

Another possible explanation for our results is the connection between GPCR iondependency and glutamate receptors. Sodium ion has been long known to affect allosterically opioid receptor binding (Katritch et al., 2014). In fact, a distinctive sodium binding pocket was discovered recently on MOP and DOP receptors (Fenalti et al., 2014; Huang et al., 2015). Hence, ionotropic glutamate receptors (NMDA, AMPA and kainate receptors etc.) being ligand-gated non-selective cation channels, may alter sodium ion concentrations induced by KYNA/KYNA1, which than may trigger an altered opioid receptor binding. This could be a plausible explanation for the increased DOP receptor agonist potency after KYNA1 treatment in the cortex (Fig. 2C).

Since only the 30 minutes duration time showed significant results (Table 1), we carried out HPLC measurements of KYNA1 and KYNA concentration levels in the CSF following 30 minute treatment. As expected the KYNA CSF concentration levels dramatically reduced compared to plasma levels, while in case of KYNA1 there was only a minor difference (Fig. 3). This proves that KYNA1 passes through the blood-brain barrier more easily than KYNA, which is in agreement with previous studies (Nagy et al., 2011). Additionally, KYNA1 concentrations were significantly lower in plasma compared to KYNA indicating that KYNA1 might have been metabolized to KYNA.

The observed effect after 30 minutes in vivo KYNA1 treatment might be at some part KYNA related. To examine this possibility G-protein activity studies were carried out in cortex 
and striatum slices treated in vitro with KYNA1, KYNA and MK-801 in isolated organ baths for 30 minutes. With this setup we can exclude or at least minimize the peripheral metabolism and elimination of KYNA1 and also exclude the BBB from the system, yet again the possible receptorreceptor interactions can remain intact. Accordingly, KYNA1 displayed the same effect as in in vivo experiments (similar to KYNA and MK-801), thus KYNA1 itself does affect opioid receptor G-protein activity. However, in case of KOP receptor in the cortex, the effect was opposite compared to in vivo experiments (Fig. 4B vs. 2B). Additionally, in some cases the in vitro results showed significant alterations where the in vivo setup did not. For instance, in the in vivo experiments KYNA1 did not alter the G-protein activity of DOP receptors expressed in the cortex, whereas in vitro this parameter was reduced (Fig. $4 \mathrm{C}$ vs. $2 \mathrm{C}$ ).

These differences between in vivo and in vitro results might be due to rapid peripheral metabolism of the compounds and the presence of the BBB. However, the main effect - which is decreasing the activity of opioid receptors - can be seen in both experimental setups. The different levels of G-proteins or receptors could be another possible explanation. The most striking result was the increase of KOP G-protein activity, which was only observed in the cortex following in vivo KYNA1 treatment (Fig 2B). It has been demonstrated that a bolus i.p. injection of a very high dose of KYNA can cause a decrease in the cerebral blood flow, which reduction was more significant in the cortex area (Varga et al., unpublished). KOP receptors are known to contribute to neuroprotection in animal models of cerebral ischemia (Goyagi et al., 2003; Fang et al., 2013). The increased KOP receptor activity induced by KYNA1 treatment might be due to a compensatory mechanism of the KOP receptor, representing its neuroprotective effect against reduced cortex blood flow. Furthermore, during this mechanism KYNA1 might be converted to KYNA in the cortex, exerting its vasoconstrictor effect at high dosage. KYNA treatment did not 
affect KOP receptor activity in the cortex most probably because of its poor BBB penetration. In other words, KYNA did not reach the necessary concentration levels in the cortex to reduce the blood flow in this area, thus it did not trigger the compensatory mechanism of the KOP receptor system.

\section{CONCLUSIONS}

The present study for the first time provides evidence for an indirect, NMDA receptormediated mechanism regarding the effects of KYNA/KYNA1 on opioid receptor function at the receptor-G-protein level. Thus KYNA and KYNA1 might be possible drug candidates for controlling the activity of the opioid system via the NMDA receptor, for instance, during opioid withdrawing in addiction therapy or pain management.

\section{ACKNOWLEDGEMENTS}

This study was supported by the National Research Development and Innovation Office (NKFIH, grant number: OTKA 108518), the National Brain Research Program (NAP, grant number: NAP-KTIA-13-NAP-A-III/9), the Euroheadpain-FP7-Health-2013-Innovation (grant number: 602633) and the Economic Development and Innovation Operational Programme (GINOP, grant number: GINOP-2.3.2-15-2016-00034). The authors would like to thank Dr. Mária Wollemann for the critical reading of the manuscript.

\section{CONFLICT OF INTEREST}

The authors confirm that there is no conflict of interest in this article. 


\section{REFERENCES}

Benyhe, S., Zádor, F., \& Ötvös, F. (2015) Biochemistry of opioid (morphine) receptors: Binding, structure and molecular modelling. Acta Biol. Szeged., 59, 17-37.

Burford, N., Wang, D., \& Sadee, W. (2000) G-protein coupling of mu-opioid receptors (OP3): elevated basal signalling activity. Biochem. J., 537, 531-537.

Corbett, A.D., Henderson, G., McKnight, A.T., \& Paterson, S.J. (2006) 75 years of opioid research: the exciting but vain quest for the Holy Grail. Br. J. Pharmacol., 147 Suppl, S153-62.

Cosi, C., Mannaioni, G., Cozzi, A., Carlà, V., Sili, M., Cavone, L., Maratea, D., \& Moroni, F. (2011) G-protein coupled receptor 35 (GPR35) activation and inflammatory pain: Studies on the antinociceptive effects of kynurenic acid and zaprinast. Neuropharmacology, $\mathbf{6 0}$, $1227-1231$.

Fang, S., Xu, H., Lu, J., Zhu, Y., \& Jiang, H. (2013) Neuroprotection by the Kappa-Opioid Receptor Agonist, BRL52537, is Mediated via Up-Regulating Phosphorylated Signal Transducer and Activator of Transcription-3 in Cerebral Ischemia/Reperfusion Injury in Rats. Neurochem. Res., 38, 2305-2312.

Fenalti, G., Giguere, P.M., Katritch, V., Huang, X.-P., Thompson, A.A., Cherezov, V., Roth, B.L., \& Stevens, R.C. (2014) Molecular control of $\delta$-opioid receptor signalling. Nature, 506, 191-196.

Füvesi, J., Somlai, C., Németh, H., Varga, H., Kis, Z., Farkas, T., Károly, N., Dobszay, M., Penke, Z., Penke, B., Vécsei, L., \& Toldi, J. (2004) Comparative study on the effects of 
kynurenic acid and glucosamine-kynurenic acid. Pharmacol. Biochem. Behav., 77, 95-102.

Goyagi, T., Toung, T.J.K., Kirsch, J.R., Traystman, R.J., Koehler, R.C., Hurn, P.D., \& Bhardwaj, A. (2003) Neuroprotective -Opioid Receptor Agonist BRL 52537 Attenuates IschemiaEvoked Nitric Oxide Production In Vivo in Rats. Stroke, 34, 1533-1538.

Gracy, K.N. \& Pickel, V.M. (1996) Ultrastructural immunocytochemical localization of the Nmethyl-D-aspartate receptor and tyrosine hydroxylase in the shell of the rat nucleus accumbens. Brain Res., 739, 169-181.

Gracy, K.N., Svingos, A.L., \& Pickel, V.M. (1997) Dual Ultrastructural Localization of $\mu$ Opioid Receptors and NMDA-Type Glutamate Receptors in the Shell of the Rat Nucleus Accumbens. J. Neurosci., 17.

Heyliger, S.O., Goodman, C.B., Ngong, J.M., \& Soliman, K.F. (1998) The analgesic effects of tryptophan and its metabolites in the rat. Pharmacol. Res., 38, 243-250.

Hiller, J.M., Zhang, Y., Bing, G., Gioannini, T.L., Stone, E.A., \& Simon, E.J. (1994) Immunohistochemical localization of mu-opioid receptors in rat brain using antibodies generated against a peptide sequence present in a purified mu-opioid binding protein. Neuroscience, 62, 829-841.

Horvath, G., Kekesi, G., Tuboly, G., \& Benedek, G. (2007) Antinociceptive interactions of triple and quadruple combinations of endogenous ligands at the spinal level. Brain. Res., 1155, $42-48$.

Huang, W., Manglik, A., Venkatakrishnan, A.J., Laeremans, T., Feinberg, E.N., Sanborn, A.L., 
Kato, H.E., Livingston, K.E., Thorsen, T.S., Kling, R.C., Granier, S., Gmeiner, P., Husbands, S.M., Traynor, J.R., Weis, W.I., Steyaert, J., Dror, R.O., \& Kobilka, B.K. (2015) Structural insights into $\mu$-opioid receptor activation. Nature, 524, 315-321.

Kam, A.Y.F., Liao, D., Loh, H.H., \& Law, P.-Y. (2010) Morphine induces AMPA receptor internalization in primary hippocampal neurons via calcineurin-dependent dephosphorylation of GluR1 subunits. J. Neurosci., 30, 15304-15316.

Katritch, V., Fenalti, G., Abola, E.E., Roth, B.L., Cherezov, V., \& Stevens, R.C. (2014) Allosteric sodium in class A GPCR signaling. Trends Biochem. Sci., 39, 233-244.

Kekesi, G., Joo, G., Csullog, E., Dobos, I., Klimscha, W., Toth, K., Benedek, G., \& Horvath, G. (2002) The antinociceptive effect of intrathecal kynurenic acid and its interaction with endomorphin-1 in rats. Eur. J. Pharmacol., 445, 93-96.

Koek, W., Colpaert, F.C., \& Vignon, J. (1993) Effects of phencyclidine-type drugs in rats discriminating fentanyl from saline: pharmacological and behavioral characterization of intermediate levels of drug lever selection. J. Pharmacol. Exp. Ther., 264, 746-756.

Kornhuber, J., Mack-Burkhardt, F., Kornhuber, M.E., \& Riederer, P. (1989) [3H]MK-801 binding sites in post-mortem human frontal cortex. Eur. J. Pharmacol., 162, 483-490.

Kotlińska, J. (2001) Attenuation of morphine dependence and withdrawal by glycine B site antagonists in rats. Pharmacol. Biochem. Behav., 68, 157-161.

Lovelace, M.D., Varney, B., Sundaram, G., Lennon, M.J., Lim, C.K., Jacobs, K., Guillemin, G.J., \& Brew, B.J. (2016) Recent evidence for an expanded role of the kynurenine pathway 
of tryptophan metabolism in neurological diseases. Neuropharmacology, http://dx.doi.org/10.1016/j.neuropharm.2016.03.024.

Mao, J. (1999) NMDA and opioid receptors: their interactions in antinociception, tolerance and neuroplasticity. Brain. Res. Rev., 30, 289-294.

Marek, P., Ben-Eliyahu, S., Gold, M., \& Liebeskind, J.C. (1991) Excitatory amino acid antagonists (kynurenic acid and MK-801) attenuate the development of morphine tolerance in the rat. Brain Res., 547, 81-88.

Martin, G., Nie, Z., \& Siggins, G.R. (1997) $\mu$-Opioid Receptors Modulate NMDA ReceptorMediated Responses in Nucleus Accumbens Neurons. J. Neurosci., 17.

Mecs, L., Tuboly, G., Nagy, E., Benedek, G., \& Horvath, G. (2009) The peripheral antinociceptive effects of endomorphin-1 and kynurenic acid in the rat inflamed joint model. Anesth. Analg., 109, 1297-1304.

Morgan, M.M., Bobeck, E.N., \& Ingram, S.L. (2009) Glutamate modulation of antinociception, but not tolerance, produced by morphine microinjection into the periaqueductal gray of the rat. Brain Res., 1295, 59-66.

Nagy, K., Plangár, I., Tuka, B., Gellért, L., Varga, D., Demeter, I., Farkas, T., Kis, Z., Marosi, M., Zádori, D., Klivényi, P., Fülöp, F., Szatmári, I., Vécsei, L., \& Toldi, J. (2011) Synthesis and biological effects of some kynurenic acid analogs. Bioorg. Med. Chem., 19, 7590-7596.

Párdutz, A., Fejes, A., Bohár, Z., Tar, L., Toldi, J., \& Vécsei, L. (2012) Kynurenines and headache. J. Neural. Transm., 119, 285-296. 
Pineda-Farias, J.B., Pérez-Severiano, F., González-Esquivel, D.F., Barragán-Iglesias, P., BravoHernández, M., Cervantes-Durán, C., Aguilera, P., Ríos, C., \& Granados-Soto, V. (2013) The L-kynurenine-probenecid combination reduces neuropathic pain in rats. Eur. J. Pain, 17, 1365-1373.

R Core Team (2014) R: A Language and Environment for Statistical Computing. R Foundation for Statistical Computing, Vienna, Austria.

Resta, F., Masi, A., Sili, M., Laurino, A., Moroni, F., \& Mannaioni, G. (2016) Kynurenic acid and zaprinast induce analgesia by modulating HCN channels through GPR35 activation. Neuropharmacology, 108, 136-143.

Safrany-Fark, A., Petrovszki, Z., Kekesi, G., Keresztes, C., Benedek, G., \& Horvath, G. (2015) Telemetry monitoring for non-invasive assessment of changes in core temperature after spinal drug administration in freely moving rats. J. Pharmacol. Toxicol. Methods, 72, 1925 .

Scavone, J.L., Asan, E., \& Van Bockstaele, E.J. (2011) Unraveling glutamate-opioid receptor interactions using high-resolution electron microscopy: implications for addiction-related processes. Exp. Neurol., 229, 207-213.

Sim, L.J. \& Childers, S.R. (1997) Anatomical distribution of mu, delta, and kappa opioid- and nociceptin/orphanin FQ-stimulated [35S]guanylyl-5'-O-(gamma-thio)-triphosphate binding in guinea pig brain. J. Comp. Neurol., 386, 562-572.

Stone, T.W. (1993) Neuropharmacology of quinolinic and kynurenic acids. Pharmacol. Rev., 45, 309-379. 
Stone, T.W. \& Darlington, L.G. (2013) The kynurenine pathway as a therapeutic target in cognitive and neurodegenerative disorders. Br J Pharmacol, 169, 1211-1227.

Svingos, A.L., Moriwaki, A., Wang, J.B., Uhl, G.R., \& Pickel, V.M. (1996) Ultrastructural Immunocytochemical Localization of $\mu$-Opioid Receptors in Rat Nucleus Accumbens: Extrasynaptic Plasmalemmal Distribution and Association with Leu5-Enkephalin. $J$. Neurosci., 16.

Traynor, J.R. \& Nahorski, S.R. (1995) Modulation by mu-opioid agonists of guanosine-5'-O-(3[35S]thio)triphosphate binding to membranes from human neuroblastoma SH-SY5Y cells. Mol. Pharmacol., 47, 848-854.

Tuboly, G., Tar, L., Bohar, Z., Safrany-Fark, A., Petrovszki, Z., Kekesi, G., Vecsei, L., Pardutz, A., \& Horvath, G. (2015) The inimitable kynurenic acid: the roles of different ionotropic receptors in the action of kynurenic acid at a spinal level. Brain Res. Bull., 112, 52-60.

Vécsei, L., Szalárdy, L., Fülöp, F., \& Toldi, J. (2013) Kynurenines in the CNS: recent advances and new questions. Nat. Rev. Drug. Discov., 12, 64-82.

Wong, E.H., Kemp, J.A., Priestley, T., Knight, A.R., Woodruff, G.N., \& Iversen, L.L. (1986) The anticonvulsant MK-801 is a potent N-methyl-D-aspartate antagonist. Proc. Natl. Acad. Sci. U. S. A., 83, 7104-7108.

Zádor, F., Samavati, R., Szlávicz, E., Tuka, B., Bojnik, E., Fülöp, F., Toldi, J., Vécsei, L., \& Borsodi, A. (2014) Inhibition of Opioid Receptor Mediated G-Protein Activity After Chronic Administration of Kynurenic Acid and its Derivative without Direct Binding to Opioid Receptors. CNS Neurol. Disord. - Drug Targets, 13, 1520-1529. 